\title{
Studies on manufactured sand effect on mechanical properties of geopolymer concrete as replacement of river sand in fine aggregate.
}

\author{
K. Veera Babu ${ }^{1 *}, T$. Srinivas ${ }^{1}$ and Mahathi Tummala ${ }^{2}$ \\ ${ }^{1}$ Assistant Professor, Department of Civil Engineering, GRIET, Hyderabad, India. \\ ${ }^{1}$ Professor, Department of Civil Engineering, GRIET, Hyderabad, India. \\ ${ }^{2}$ U.G.Student, Department of Civil Engineering, JNTUH, Hyderabad, India.
}

\begin{abstract}
Concrete is the most adaptable, long-lasting, and dependable construction material on the planet. There are numerous environmental concerns associated with the production of OPC, and natural sand is becoming more expensive and scarce as a result of unlawful river sand dredging. The greatest replacement material for traditional concrete is geopolymer concrete with low calcium fly ash. The purpose of this paper is to investigate the mechanical properties of geopolymer concrete of grades G30 and G50, which are equivalent to M30 and M50, when river sand is substituted in various quantities with manufactured sand, such as $0 \%, 10 \%, 20 \%, 30 \%, 40 \%, 50 \%, 60 \%, 70 \%, 80 \%, 90 \%$, and $100 \%$. When compared to the equivalent grades of controlled concrete, geopolymer concrete improves mechanical properties such as compressive, tensile, and flexural strengths.
\end{abstract}

\section{Introduction}

Construction is currently one of the fastest developing fields on the planet. Concrete is the most extensively used man-made substance on the earth. Globally annual output of OPC is around 4.1 billion metric tonnes, according to international data. Within the next ten years, this quantity will increase by more than $25 \%$. (ShiramMarathe et al. [2016]). "The amount of carbon dioxide released during OPC manufacturing due to lime stone calcinations and fossil fuel burning is on the order of one ton for every ton of OPC produced, which is a serious issue for sustainable development, humaninduced global warming is produced by the release of greenhouse gases into the atmosphere, such as carbon dioxide, $\mathrm{CO} 2$ accounts for around 65 percent of global warming among greenhouse gases, the cement sector accounts for roughly 7 percent of all carbon dioxide emissions into the environment".

On the contrary, "the abundance and availability of bi product materials such as fly ash (FA), ground granulated blast furnace slag (GGBS), red mud and rice husk ash (RHA) around the world opens up the possibility of using these by-products of various industries as ${ }^{1}$ a partial replacement for OPC in concrete". Given all of these considerations, an alternate material to Ordinary Portland Cement is required. For this challenge, geopolymer concrete is a very promising solution.

\footnotetext{
*Corresponding Author: kveerababu2542@gmail.com
}

Geopolymers was coined by Joseph Davidovits in 1972 to describe zeolite-like polymers. Alumina-silicate polymers are known as geopolymers that are created by geopolymerizing alumina-silicate monomers in alkaline solution into amorphous and three-dimensional structures.

However, little effort has been made to determine the mechanical behaviour of "geopolymer concrete based on low calcium fly ash and slag in place of cement and manufactured sand as fine aggregate, such as compressive, split tensile and flexural strength".

\section{Materials}

\subsection{Ordinary Portland cement}

The 53-grade of regular Portland cement was utilised in the experiments. The physical properties on cement were evaluated in conformance with IS: 4031-1968 and found to meet different IS 12629-1987 requirements.

\subsection{Fine aggregate}

River and manufactured sands, both are locally available, which are free from organic pollutants and conformed to IS: $383-1970$ used as fine aggregate. The sieve analysis test has been done and confirmed that the river sand is belongs to Zone II. M-sand sand preparation also followed the same pattern as that of river sand. 


\subsection{Coarse Aggregate}

In this study, "coarse aggregate is crushed angular aggregate with a maximum size of $20 \mathrm{~mm}$ supplied from local crushing facilities, the physical properties of coarse aggregate are examined in line with IS 2386-1963, including specific gravity, bulk density, flakiness, and elongation index".

\subsection{Fly Ash}

"In this work, Class F-fly ash from the Vijayawada thermal power unit in Andhra Pradesh was used".

Table 1. Manufactured Sand Physical Properties

\begin{tabular}{|c|c|c|c|}
\hline $\begin{array}{l}\mathbf{S} . \\
\mathbf{N} \\
\mathbf{O}\end{array}$ & Property & Method & $\begin{array}{c}\text { Fine } \\
\text { Aggregate }\end{array}$ \\
\hline 1 & $\begin{array}{l}\text { Specific } \\
\text { Gravity }\end{array}$ & $\begin{array}{c}\text { Pycnometer } \\
\text { IS Code:2386 -1986 } \\
\text { (Part-3) }\end{array}$ & 2.71 \\
\hline 2 & $\begin{array}{c}\text { Bulk } \\
\text { Density } \\
\text { (compact } \\
\text { ed) }\end{array}$ & $\begin{array}{c}\text { IS Code:2386 -1986 } \\
\text { (Part-3) }\end{array}$ & $\begin{array}{c}1720 \\
\mathrm{~kg} / \mathrm{cm}^{3}\end{array}$ \\
\hline 3 & $\begin{array}{c}\text { Bulk } \\
\text { Density } \\
\text { (loose) }\end{array}$ & $\begin{array}{c}\text { IS Code:2386 -1986 } \\
\text { (Part-3) }\end{array}$ & $\begin{array}{l}1664.27 \\
\mathrm{~kg} / \mathrm{cm}^{3}\end{array}$ \\
\hline 4 & $\begin{array}{l}\text { Fineness } \\
\text { Modulus }\end{array}$ & $\begin{array}{c}\text { Sieve Analysis (IS } \\
\text { Code: } 2386 \text {-1963(Part- } \\
\text { 2)) }\end{array}$ & 2.67 \\
\hline 5 & Bulking & $\begin{array}{c}\text { IS Code:2386 -1986 } \\
\text { (Part-3) }\end{array}$ & $\begin{array}{l}4 \% \text { of } \\
\text { Water } \\
\text { content }\end{array}$ \\
\hline 6 & Grading & & Zone --II \\
\hline
\end{tabular}

\subsection{Ground Granulated Blast Furnace Slag(GGBS)}

GGBS (Ground Granulated Blast Furnace Slag) is a steel manufacturing by product. Slag from a blast furnace is defined as "the non-metallic product consisting essentially of calcium silicates and other bases that is developed in a molten condition simultaneously with iron in a blast furnace". GGBS was used to replace around $15 \%$ of the binders by mass.

\subsection{Water}

Concrete is mixed with water that is free of chemicals, oils, and other contaminants, according to IS: 456:2000.

\subsection{Sodium Hydroxide}

One of the main elements in geopolymer concrete is sodium hydroxide. "Sodium hydroxide pellets are available from local laboratory chemical vendors in Hyderabad and have the following specifications". Table 2 lists the specifications provided by the providers.

\subsection{Sodium Silicate Solution}

"Sodium silicate solution, a type of alkaline liquid, is crucial in the polymerisation process, this substance is obtained from Hyderabad local laboratory chemical dealers". Table 3 lists the specifications provided by the providers.

Table 2. NaOH Physical properties

\begin{tabular}{|c|c|}
\hline Molar mass & $40 \mathrm{gm} / \mathrm{mol}$ \\
\hline Appearance & White solid \\
\hline Density & $2.1 \mathrm{gram} / \mathrm{cm}^{3}$ \\
\hline Melting temperature & $318^{\circ} \mathrm{C}$ \\
\hline Boiling temperature & $1390^{\circ} \mathrm{C}$ \\
\hline $\begin{array}{c}\text { When dissolved in water, the } \\
\text { amount of heat released }\end{array}$ & $266 \mathrm{cal} / \mathrm{gram}$ \\
\hline
\end{tabular}

Table 3. $\mathrm{Na}_{2} \mathrm{SiO}_{3}$ Solution Properties

\begin{tabular}{|c|c|}
\hline Specific Gravity & 1.57 \\
\hline Molar mass & $122.06 \mathrm{gm} / \mathrm{mol}$ \\
\hline $\mathrm{Na}_{2} \mathrm{O}$ (by mass) & $14.35 \%$ \\
\hline $\mathrm{SiO}_{2}$ (by mass) & $30.00 \%$ \\
\hline Water (by mass) & $55.00 \%$ \\
\hline $\begin{array}{c}\text { Ratio of weight ( } \mathrm{SiO}_{2} \text { to } \\
\mathrm{Na}_{2} \mathrm{O} \text { ) }\end{array}$ & 2.09 \\
\hline Molarity ratio & 0.97 \\
\hline
\end{tabular}

\subsection{Super Plasticizer}

As a water-reducing admixture, Fosroc Chemical India Ltd.'s superplasticizer GLENIUM B233 was used, which improves workability.

\section{Experimental Investigations}

The predominantly mixing sodium hydroxide $(\mathrm{NaOH})$ pellets with sodium silicate (Na2SiO3) solution produced an alkaline activator solution according to the mix proportions in the preparation of specimens. 30 minutes before the casting, make the alkaline solution. "G30 and G50 geopolymer concrete grades were made with $12 \mathrm{M}$ and $16 \mathrm{M}$ of $\mathrm{NaOH}$ respectively in this experiment and the sodium silicate to sodium hydroxide ratio was 2.5 is used". "To make geopolymer concrete, the fly ash, GGBS, fine aggregates, coarse aggregates, and alkaline activator solution are weighted according to the mix design and mixed in the laboratory using a tilting drum type concrete mixer". 


\subsection{Mix Design of Concrete}

Table 4. Concrete Mix Proportions

\begin{tabular}{|l|l|}
\hline $\begin{array}{l}\text { Controlled Concrete of standard grade } \\
\text { (M30) }\end{array}$ & $1: 1.89: 3.27: 0.45$ \\
\hline $\begin{array}{l}\text { Standard grade (G30) of Geopolymer } \\
\text { Concrete }\end{array}$ & $1: 1.89: 3.27: 0.45$ \\
\hline $\begin{array}{l}\text { Standard grade (M50) of Controlled } \\
\text { Concrete }\end{array}$ & $1: 1.35: 3.16: 0.4$ \\
\hline $\begin{array}{l}\text { Geopolymer Concrete of Standard } \\
\text { grade (G50) }\end{array}$ & $1: 1.35: 3.16: 0.4$ \\
\hline
\end{tabular}

The table 4 shows the mix proportions for the current investigations, which are prepared according to IS 10262-2009.

\section{Test Results}

\subsection{Compressive Strength}

The cube specimens, which were $150 \mathrm{~mm}$ X $150 \mathrm{~mm}$ X $150 \mathrm{~mm}$ in dimension, were truly tested for the various compositions of mix as given in tables 5 and 6 at 3, 7, and 28 days in compliance with IS Code: $516-1969$, and the findings were also presented in tables 5 and 6 .

The river sand replaced with manufactured sand for every $10 \%$ starting from $0 \%$ and ends with $100 \%$ as shown in table 5 and 6 , which is the main objective of this work. Based on these mix proportions the strengths are evaluated.

Table 5. Compressive strength of M30 and G30 grades Concrete

\begin{tabular}{|c|c|c|c|c|c|c|c|}
\hline \multirow[t]{2}{*}{$\begin{array}{l}\text { Typ } \\
\text { e of } \\
\text { Mix }\end{array}$} & \multicolumn{4}{|c|}{$\begin{array}{l}\text { M30 grade Compressive } \\
\text { Strength }\left(\mathrm{N} / \mathrm{mm}^{2}\right)\end{array}$} & \multicolumn{3}{|c|}{$\begin{array}{c}\text { G30 grade } \\
\text { Compressive } \\
\text { Strength } \\
\left(\mathbf{N} / \mathbf{m m}^{2}\right)\end{array}$} \\
\hline & $\begin{array}{l}\text { M- } \\
\text { Sand } \\
\%\end{array}$ & $\begin{array}{c}3 \\
\text { Days }\end{array}$ & $\begin{array}{c}7 \\
\text { Days }\end{array}$ & $\begin{array}{c}28 \\
\text { Days }\end{array}$ & $\begin{array}{c}3 \\
\text { Days }\end{array}$ & $\begin{array}{c}7 \\
\text { Days }\end{array}$ & $\begin{array}{c}28 \\
\text { Days }\end{array}$ \\
\hline $\begin{array}{c}\text { Mix } \\
1\end{array}$ & 0 & $\begin{array}{c}19.4 \\
5\end{array}$ & $\begin{array}{c}27.6 \\
8\end{array}$ & $\begin{array}{c}38.3 \\
9\end{array}$ & $\begin{array}{c}33.4 \\
5\end{array}$ & $\begin{array}{c}35.2 \\
9\end{array}$ & $\begin{array}{c}38.5 \\
3\end{array}$ \\
\hline $\begin{array}{c}\operatorname{Mix} \\
2\end{array}$ & 10 & $\begin{array}{c}19.8 \\
7\end{array}$ & $\begin{array}{c}27.8 \\
2\end{array}$ & $\begin{array}{c}38.7 \\
2\end{array}$ & $\begin{array}{c}33.8 \\
6\end{array}$ & $\begin{array}{c}35.3 \\
7\end{array}$ & $\begin{array}{c}38.6 \\
0\end{array}$ \\
\hline $\begin{array}{c}\operatorname{Mix} \\
3\end{array}$ & 20 & $\begin{array}{c}20.2 \\
8\end{array}$ & $\begin{array}{c}28.1 \\
2\end{array}$ & $\begin{array}{c}38.9 \\
7\end{array}$ & $\begin{array}{c}34.1 \\
2\end{array}$ & $\begin{array}{c}35.9 \\
2\end{array}$ & $\begin{array}{c}38.7 \\
3\end{array}$ \\
\hline $\begin{array}{c}\operatorname{Mix} \\
4\end{array}$ & 30 & $\begin{array}{c}20.9 \\
4\end{array}$ & $\begin{array}{c}28.5 \\
3\end{array}$ & $\begin{array}{c}39.3 \\
8\end{array}$ & $\begin{array}{c}34.7 \\
9\end{array}$ & $\begin{array}{c}36.5 \\
4\end{array}$ & $\begin{array}{c}39.3 \\
5\end{array}$ \\
\hline Mix & 40 & 21.3 & 28.9 & 39.8 & 35.0 & 36.7 & 39.8 \\
\hline
\end{tabular}

\begin{tabular}{|c|c|c|c|c|c|c|c|}
\hline 5 & & 6 & 7 & 9 & 4 & 9 & 7 \\
\hline Mix & 50 & 21.9 & 29.3 & 40.0 & 35.5 & 37.1 & 40.2 \\
\hline 6 & & 8 & 1 & 3 & 6 & 6 & 9 \\
\hline Mix & 60 & 22.3 & 29.8 & 40.5 & 35.8 & 37.9 & 41.0 \\
\hline 7 & & 2 & 4 & 6 & 9 & 3 & 3 \\
\hline Mix & 70 & 22.7 & 30.1 & 40.9 & 36.2 & 38.3 & 41.2 \\
\hline 8 & & 1 & 8 & 7 & 5 & 6 & 3 \\
\hline Mix & 80 & 23.1 & 30.6 & 41.1 & 36.6 & 38.7 & 41.8 \\
\hline 9 & & 3 & 7 & 1 & 5 & 9 & 7 \\
\hline Mix & 90 & 23.6 & 30.9 & 41.2 & 37.0 & 39.0 & 42.2 \\
\hline 10 & & 9 & 5 & 9 & 6 & 4 & 1 \\
\hline Mix & 10 & 24.0 & 31.6 & 41.3 & 37.4 & 39.2 & 42.3 \\
\hline 11 & 0 & 3 & 4 & 2 & 2 & 5 & 7 \\
\hline
\end{tabular}

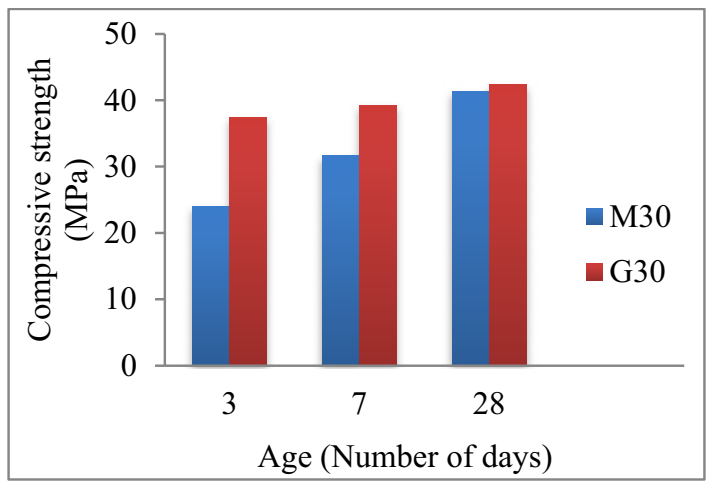

Figure 1.Compressive Strengths of M30 \& G30 for Mix 11

Table 6. Compressive Strength of M50 and G50 grades Concrete

\begin{tabular}{|c|c|c|c|c|c|c|c|}
\hline \multirow[t]{2}{*}{$\begin{array}{l}\text { Typ } \\
\text { e of } \\
\text { Mix }\end{array}$} & \multicolumn{4}{|c|}{$\begin{array}{l}\text { M50 grade Compressive } \\
\text { Strength }\left(\mathrm{N} / \mathrm{mm}^{2}\right)\end{array}$} & \multicolumn{3}{|c|}{$\begin{array}{c}\text { G50 grade } \\
\text { Compressive } \\
\text { Strength } \\
\left(\mathbf{N} / \mathbf{m m}^{2}\right)\end{array}$} \\
\hline & $\begin{array}{c}\text { M- } \\
\text { Sand } \\
\%\end{array}$ & $\begin{array}{c}3 \\
\text { Days }\end{array}$ & $\begin{array}{c}7 \\
\text { Days }\end{array}$ & $\begin{array}{c}28 \\
\text { Days }\end{array}$ & $\left|\begin{array}{c}3 \\
\text { Days }\end{array}\right|$ & $\begin{array}{c}7 \\
\text { Days }\end{array}$ & $\begin{array}{c}28 \\
\text { Days }\end{array}$ \\
\hline $\begin{array}{c}\text { Mix } \\
1\end{array}$ & 0 & $\begin{array}{c}28.9 \\
2\end{array}$ & $\begin{array}{c}41.0 \\
7\end{array}$ & $\begin{array}{c}58.3 \\
3\end{array}$ & $\begin{array}{c}54.1 \\
9\end{array}$ & $\begin{array}{c}55.6 \\
3\end{array}$ & $\begin{array}{c}58.3 \\
3\end{array}$ \\
\hline $\begin{array}{c}\operatorname{Mix} \\
2\end{array}$ & 10 & $\begin{array}{c}29.3 \\
1\end{array}$ & $\begin{array}{c}41.3 \\
6\end{array}$ & $\begin{array}{c}59.2 \\
1\end{array}$ & $\begin{array}{c}54.4 \\
9\end{array}$ & $\begin{array}{c}55.9 \\
7\end{array}$ & $\begin{array}{c}59.9 \\
2\end{array}$ \\
\hline $\begin{array}{c}\text { Mix } \\
3\end{array}$ & 20 & $\begin{array}{c}29.8 \\
4\end{array}$ & $\begin{array}{c}41.8 \\
2\end{array}$ & $\begin{array}{c}59.5 \\
6\end{array}$ & $\begin{array}{c}54.8 \\
6\end{array}$ & $\begin{array}{c}56.2 \\
8\end{array}$ & $\begin{array}{c}60.3 \\
4\end{array}$ \\
\hline $\begin{array}{c}\operatorname{Mix} \\
4\end{array}$ & 30 & $\begin{array}{c}30.2 \\
3\end{array}$ & $\begin{array}{c}42.2 \\
1\end{array}$ & $\begin{array}{c}59.9 \\
7\end{array}$ & $\begin{array}{c}55.1 \\
2\end{array}$ & $\begin{array}{c}56.9 \\
3\end{array}$ & $\begin{array}{c}60.7 \\
9\end{array}$ \\
\hline
\end{tabular}




\begin{tabular}{|c|c|c|c|c|c|c|c|}
\hline $\begin{array}{c}\text { Mix } \\
5\end{array}$ & 40 & $\begin{array}{c}30.6 \\
4\end{array}$ & $\begin{array}{c}42.6 \\
4\end{array}$ & $\begin{array}{c}60.2 \\
4\end{array}$ & $\begin{array}{c}55.3 \\
6\end{array}$ & $\begin{array}{c}57.3 \\
6\end{array}$ & $\begin{array}{c}61.0 \\
6\end{array}$ \\
\hline $\begin{array}{c}\text { Mix } \\
6\end{array}$ & 50 & $\begin{array}{c}30.8 \\
9\end{array}$ & $\begin{array}{c}42.9 \\
5\end{array}$ & $\begin{array}{c}60.7 \\
5\end{array}$ & $\begin{array}{c}55.9 \\
7\end{array}$ & $\begin{array}{c}57.8 \\
9\end{array}$ & $\begin{array}{c}61.4 \\
9\end{array}$ \\
\hline $\begin{array}{c}\text { Mix } \\
7\end{array}$ & 60 & $\begin{array}{c}31.3 \\
0\end{array}$ & $\begin{array}{c}43.3 \\
1\end{array}$ & $\begin{array}{c}60.9 \\
3\end{array}$ & $\begin{array}{c}56.3 \\
6\end{array}$ & $\begin{array}{c}58.3 \\
7\end{array}$ & $\begin{array}{c}61.9 \\
4\end{array}$ \\
\hline $\begin{array}{c}\text { Mix } \\
8\end{array}$ & 70 & $\begin{array}{c}31.8 \\
5\end{array}$ & $\begin{array}{c}43.8 \\
1\end{array}$ & $\begin{array}{c}61.3 \\
1\end{array}$ & $\begin{array}{c}56.7 \\
8\end{array}$ & $\begin{array}{c}58.9 \\
2\end{array}$ & $\begin{array}{c}62.2 \\
6\end{array}$ \\
\hline $\begin{array}{c}\text { Mix } \\
9\end{array}$ & 80 & 32.3 & 44.3 & 61.3 & 57.8 & 59.2 & 62.2 \\
4 & 4 & 7 & 4 & 4 & 9 \\
\hline $\begin{array}{c}\text { Mix } \\
10\end{array}$ & 90 & 32.5 & 44.8 & 61.4 & 57.9 & 59.3 & 62.3 \\
8 & 9 & 8 & 6 & 8 & 6 \\
\hline Mix & 10 & 32.8 & 45.2 & 61.5 & 58.0 & 59.7 & 62.4 \\
11 & 0 & 3 & 7 & 6 & 2 & 4 & 3 \\
\hline
\end{tabular}

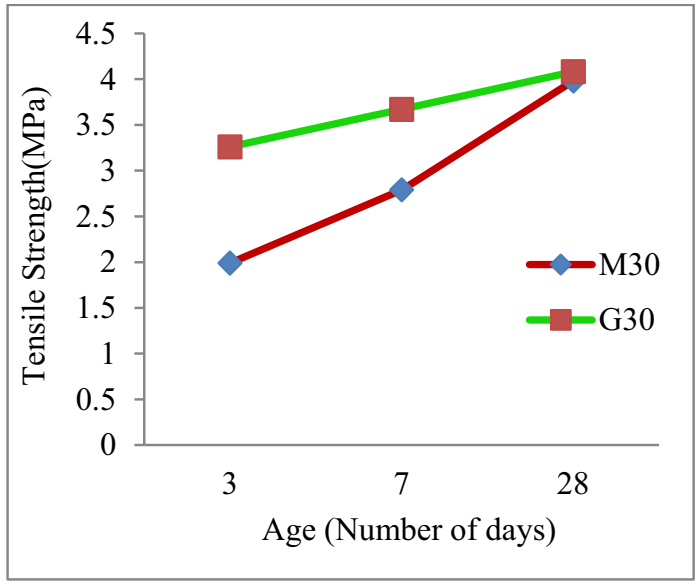

Figure 3. Split Tensile Strengths of M30 \& G30

Table 8. Split Tensile Strength of M50 \& G50 (N/ $\left.\mathrm{mm}^{2}\right)$

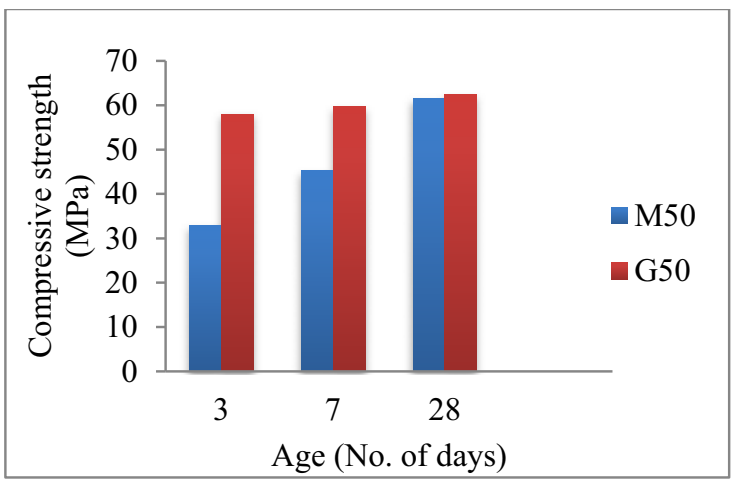

Figure 2. Compressive Strengths of M50\&G50 for Mix 11

The compressive strength results of geopolymer and controlled concrete of grades G30 and M30 are given in table 6 and G50 and M50 are given in table 6, it is observed from these tables that the strength is increased as the percentage of manufactured sand increases.

\subsection{Split Tensile Strength}

Tables 8 and 9 and figures 3 and 4 show the results of casting and testing "a concrete cylinder with a diameter of $150 \mathrm{~mm}$ and a height of $300 \mathrm{~mm}$ according to codal procedures".

Table 7: Split Tensile Strength of M30 \& G30 (N/mm²)

\begin{tabular}{|c|c|c|c|}
\hline Concrete grade & $\mathbf{3}$ days & $\mathbf{7}$ days & $\mathbf{2 8}$ days \\
\hline M30 & 1.99 & 2.79 & 3.98 \\
\hline G30 & 3.26 & 3.67 & 4.08 \\
\hline
\end{tabular}

\begin{tabular}{|c|c|c|c|}
\hline Concrete grade & 3 Days & 7 Days & 28 Days \\
\hline M50 & 2.64 & 3.69 & 5.27 \\
\hline G50 & 4.26 & 4.79 & 5.43 \\
\hline
\end{tabular}

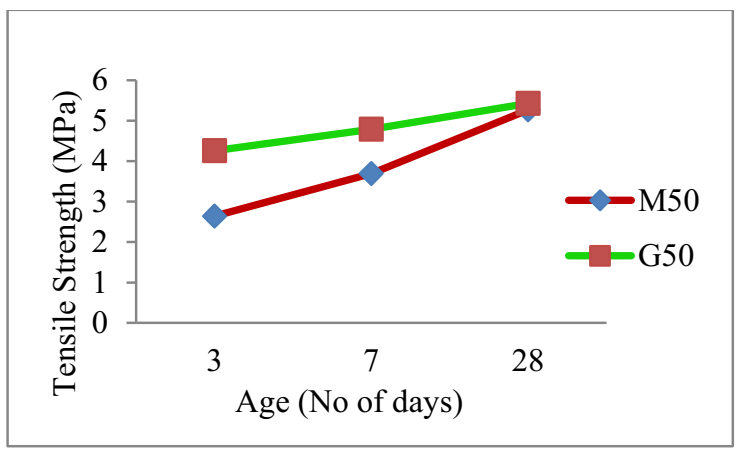

Figure 4. Split Tensile Strengths of M50 \& G50

\subsection{Flexural Strength}

"Concrete prisms of dimensions $100 \mathrm{~mm} \times 100 \mathrm{~mm} \times$ $500 \mathrm{~mm}$ are casted to determine the flexural strength of conventional and geopolymer concrete for the mix of maximum compressive strength with standard test procedures such as ASTM C 78 (third-point loading) or ASTM C 293, which is given as Modulus of Rupture (MR) in (MPa) (centre-point loading), depending on the quality, size, and amount of coarse aggregate used, it has been observed that flexural strength (MR) ranges from $10 \%$ to $20 \%$ of compressive strength". 
Table 9: Shows Flexural Strength of M30 \& G30 (MPa)

\begin{tabular}{|c|c|c|c|}
\hline Grade of Concrete & 3 Days & 7 Days & 28 Days \\
\hline M30 & 2.53 & 3.54 & 5.06 \\
\hline G30 & 4.15 & 4.67 & 5.19 \\
\hline
\end{tabular}

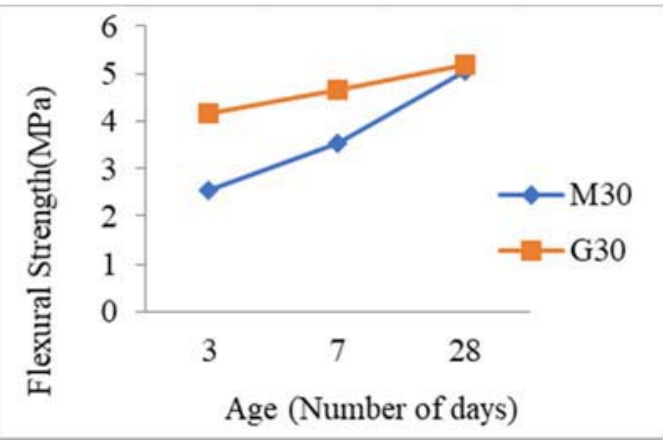

Figure 5. Flexural Strength of M30 \& G30

Table 10. Flexural Strength of M50 \& G50 (N/mm²)

\begin{tabular}{|c|r|r|r|}
\hline $\begin{array}{c}\text { Grade of } \\
\text { concrete }\end{array}$ & $\begin{array}{r}\mathbf{3} \\
\text { days }\end{array}$ & $\begin{array}{r}\mathbf{7} \\
\text { days }\end{array}$ & $\begin{array}{c}\mathbf{2 8} \\
\text { days }\end{array}$ \\
\hline M50 & 3.33 & 4.66 & 6.66 \\
\hline G50 & 5.38 & 6.05 & 6.74 \\
\hline
\end{tabular}

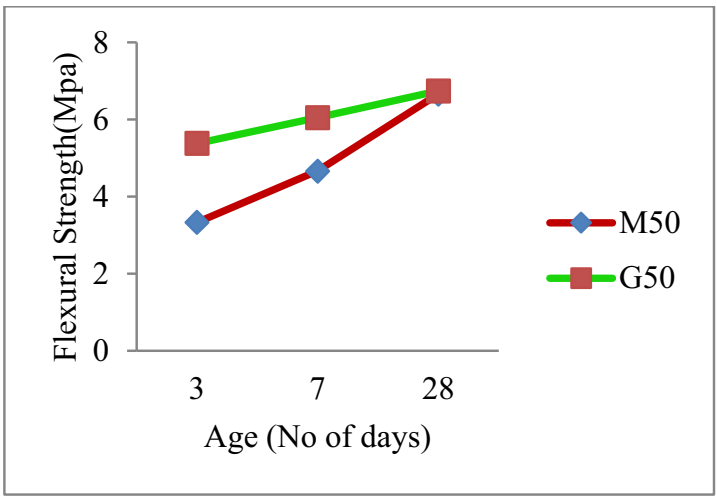

Figure 6. Flexural Strength of M50 \& G50

\section{Conclusions}

The following findings are obtained from the experimental investigations:

1. The compressive strength is increased as the percentage of manufactured sand increases in controlled and geopolymer concrete for both the grades.

2. Compressive strength for $100 \%$ replacement (table 5 and 6) is increased by $7.63 \%$ and $9.97 \%$ for M30 and G30 respectively. Similarly it is increased by $5.53 \%$ and $7.03 \%$ for M50 and G50 respectively.

3. "The split tensile strength of G30 (Table 7) increased by $2.45 \%$ and that of G50 (Table 8) increased by 2.94 percent when compared to M30 and M50 conventional concrete respectively".

4. "The flexural strength of G30 (Table 9) increased by 2.5 percent and that of G50 (Table 10) increased by 1.18 percent when compared to conventional M30 and M50 concrete respectively".

5. In both controlled and geopolymer concrete, the percentage increase in compressive strength decreases as the concrete grade increases.

Keywords. Geopolymer Concrete, River Sand, Manufactured Sand, Controlled Concrete, Mechanical Properties.

\section{References}

1. Davidovits, J. Chemistry of Geopolymeric Systems, Terminology. Geopolymer '99 International Conference, France: 9-40, (1999).

2. Genani R and Revathi A; IJSETR, Vol. 4, Issue 4, 1054(2015)

3. Hardjito, D., S. E. Wallah, D. M. J. Sumajouw\& B. V. Rangan ACI Materials Journal, Vol. 101, No. 6, 467 (2004).

4. Hardjito, D., S.E. Wallah, D.M.J. Sumajouw\& B.V. Rangan, AJSE, Vol. 6, No. 1, 77 (2005).

5. J. Guru Jawahar and G. Mounika; AJClE, volume 17, No. 1, 127(2016).

6. K. Arul priya; IJTRD, Volume 3(3), 90 (2016).

7. Dr.T Srinivas and Dr. N V Ramana Rao, IJ CET 10, 510 (2019).

8. Karthik Rao, R., Bobba, P.B., Suresh Kumar, T., Kosaraju, S. Materials Today: Proceedings, 26, pp. 3085-3089, 2019

9. M.I. Abdul Aleem and P.D. Arumairaj; Article 22, Poll Res.32(2), 139(2013).

10. M. Sugapriya et al.; IJERT, volume 06, Issue 05, 307(2017).

11. T.Srinivas and M. Abinay Raj, Int. J. of Eng.and Adv. Tech. (IJEAT), ISSN: 2249 - 8958, Volume-8 Issue-6 (2019)

12. B. T. P. Singh, B. P. Babu and Y. Satyavani, 2019 IEEE Transportation Electrification Conference (ITEC-India), 2019, pp. 1-6

13. T.srinivas and P. Manoj Anand, Int. J. of Innov. Tech. and Explor. Eng.g (IJITEE), ISSN: 22783075, Volume-8 Issue-12 (2019)

14. T.Srinivas and G. Sukesh Reddy, Int. J. of Eng.and Adv. Tech. (IJEAT), ISSN: 2249 - 8958, Volume-9 Issue-1 (2019)

15. T.Srinivas and R. N. Koushik, Int. J. of Innov. Tech. and Explor. Eng.g (IJITEE), ISSN: 22783075, Volume-8 Issue-12 (2019), PP 112-117.

16. K. Sai Gopi, Dr. T. Srinivas and S. P. Raju V, E3S Web of Conferences ICMED 184, 01084GRIET, 
28-29

February, https://doi.org/10.1051/e3sconf/2020184011084(20 20)

17. Jagannadha Kumar, M.V., Jagannadha Rao, K., Dean Kumar, B., Srinivasa Reddy, V., Int. J. of Civil Eng. and Tech., 9(7), pp. 1133-1141 (2018)

18. Ganta, J.K., Seshagiri Rao, M.V., Mousavi, S.S., Srinivasa Reddy, V., Bhojaraju, C., Structures 28, pp. 956-972 (2020)

19. Naidu, K.S.S.T., Rao, M.V.S., Reddy, V.S., Int. J. of Innov. Tech. and Explor. Eng.g (IJITEE), 8(9 Special Issue 2), pp. 641-642 (2019)

20. Chandana Priya, C., Seshagiri Rao, M.V., Srinivasa Reddy, V., Int. J. of Civil Eng. and Tech., 9(11), pp. 2218-2225 (2018)

21. K. satyanarayana, S. K. Singh, T. Buddi, K. Anil and A. Ul Haq, Advances in Materials and Processing Technologies, 6(2), 365 (2020)

22. Satya Sai Trimurty Naidu, K., Seshagiri Rao, M.V., Srinivasa Reddy, V., Int. J. of Civil Eng. and Tech., 9(11), pp. 2383-2393 (2018)

23. Supriya, Y., Srinivasa Reddy, V., Seshagiri Rao, M.V., Shrihari, S., Int. J. of Rec. Tech. and Engi., 8(3), pp. 5381-5385 (2019)

24. S. U.M. Rao,T.H. Rao, K. Satyanarayana, and B. Nagaraju, Materials Today: Proceedings, 5(2), 4958 (2018)

25. Kotkunde, N., Krishna, G., Shenoy, S.K., Gupta, A.K., Singh, S.K. International Journal of Material Forming, 10 (2), pp. 255-266 (2017)

26. Govardhan, D., Kumar, A.C.S., Murti, K.G.K., Madhusudhan Reddy, G. Materials and Design, 36, pp. 206-214. (2012)

27. Prashant Singh B.T., Babu Bobba Phaneendra and K. Suresh , E3S Web Conf., 87 (2019) 01010

28. Kumar, P., Singhal, A., Mehta, S., Mittal, A. Journal of Real-Time Image Processing, 11 (1), pp. 93-109. (2016)

29. Raghunadha Reddy, T., Vishnu Vardhan, B., Vijayapal Reddy, P. International Journal of Applied Engineering Research, 11 (5), pp. 30923102 (2016)

30. Hussaini, S.M., Krishna, G., Gupta, A.K., Singh, S.K. Journal of Manufacturing Processes, 18, pp. 151-158 (2015) 